\title{
The role of CD38 in HIV infection
}

\author{
Liqi Lu' , Jie Wang ${ }^{1}$, Qian Yang ${ }^{2}$, Xiuqiao Xie ${ }^{1}$ and Yuanshuai Huang ${ }^{1 *}$
}

\begin{abstract}
The widely-expressed molecule CD38 is a single-stranded type II transmembrane glycoprotein that is mainly involved in regulating the differentiation and activation state of the cell. CD38 has broad and complex functions, including enzymatic activity, intercellular signal transduction, cell activation, cytokine production, receptor function and adhesion activity, and it plays an important role in the physiological and pathological processes of many diseases. Many studies have shown that CD38 is related to the occurrence and development of HIV infection, and CD38 may regulate its progression through different mechanisms. Therefore, investigating the role of CD38 in HIV infection and the potential signaling pathways that are involved may provide a new perspective on potential treatments for HIV infection. In the present review, the current understanding of the roles CD38 plays in HIV infection are summarized. In addition, the specific role of CD38 in the process of HIV infection of human $\mathrm{CD}^{+}{ }^{+}$T lymphocytes is also discussed.
\end{abstract}

Keywords: HIV, CD38 molecule, Abnormal immune activation, ART

\section{Introduction}

The analysis of CD38 expression on lymphocytes has become an important tool for monitoring patients during HIV infection and has been proposed for use in the follow-up of antiretroviral therapy (ART). CD38 has prognostic utility because it marks the activation of the immune response. CD38 is not only an important prognostic marker but also an active player in HIV infection [1]. There is currently no cure or vaccine for HIV infection, and research on the CD38 molecule will further explain the development and mechanism of HIV infection. This may provide some clues about the clinical treatment of HIV infection. In the present review, the progress of research on the role and mechanisms of CD38 in HIV infection is summarized since an in-depth study of CD38 will provide some ideas about the pathogenesis, disease progression and effective treatment of HIV infection.

\footnotetext{
*Correspondence: hys@live.cn

${ }^{1}$ Department of Transfusion, The Affiliated Hospital of Southwest Medical University, 25 Taiping Road, Luzhou, Sichuan 646000, People's Republic of China

Full list of author information is available at the end of the article
}

\section{HIV infection}

Human acquired immunodeficiency virus (HIV) is a type of RNA virus with two subtypes, HIV-1 and HIV-2, with HIV-1 showing global distribution and HIV-2 being prevalent mainly in West Africa. HIV mainly attacks $\mathrm{CD} 4^{+} \mathrm{T}$ lymphocytes, causing a progressive decrease in the number of $\mathrm{CD} 4^{+} \mathrm{T}$ lymphocytes, resulting in impairment of the body's cellular immune function, and finally to the onset of AIDS. CD4 ${ }^{+} \mathrm{T}$ lymphocytes [2] and macrophages/monocytes [3] are the primary targets of HIV, but there is some evidence that other members of the hematopoietic system can support HIV infection, dendritic cells [3], natural killer (NK) cells [4] and microglia [5] are included. It was also observed that polymorphonuclear neutrophils depletion [6] and the appearance of a subset of B cells whose function is impaired [7] during the course of HIV-1 infection, but there is still no clear indication that HIV-1 can directly infect polymorphonuclear neutrophils or B cells. But the hematopoietic stem cell is not infectible with HIV, stem cells are highly resistant to HIV infection [8]. HIV infection could lead to various opportunistic infections and tumors, and eventually, it leads to death. AIDS is one of the most serious epidemics ever experienced by humanity, not only because its

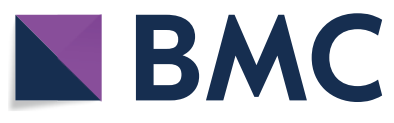

(c) The Author(s) 2021. This article is licensed under a Creative Commons Attribution 4.0 International License, which permits use, sharing, adaptation, distribution and reproduction in any medium or format, as long as you give appropriate credit to the original author(s) and the source, provide a link to the Creative Commons licence, and indicate if changes were made. The images or other third party material in this article are included in the article's Creative Commons licence, unless indicated otherwise in a credit line to the material. If material is not included in the article's Creative Commons licence and your intended use is not permitted by statutory regulation or exceeds the permitted use, you will need to obtain permission directly from the copyright holder. To view a copy of this licence, visit http://creativeco mmons.org/licenses/by/4.0/. The Creative Commons Public Domain Dedication waiver (http://creativecommons.org/publicdomain/ zero/1.0/) applies to the data made available in this article, unless otherwise stated in a credit line to the data. 
rapidity and wide spread, but also it is a disease with an extremely high mortality rate.

The characteristic loss of $\mathrm{CD}^{+} \mathrm{T}$ cells that is thought to play a key role in the development of immunodeficiency. But it is apparently that $\mathrm{CD} 4^{+} \mathrm{T}$ cell-directed viral cytopathicity alone cannot explain the course of disease [9]. The cellular immune response to human immunodeficiency virus mediated by $\mathrm{T}$ lymphocytes appears to be strong, but does not completely control the infection. Human immunodeficiency virus disrupts this control by infecting key immune cells, thereby weakening the $\mathrm{T}$ lymphocyte response. The response of cytotoxic $\mathrm{T}$ lymphocytes (CTLs) is important in controlling viral replication [10]. At the beginning of HIV infection, $\mathrm{CD}^{+}{ }^{+} \mathrm{T}$ cells are stimulated by the virus and activated into cytotoxic $\mathrm{T}$ lymphocyte (CTL), which play an important role in the control of HIV through cytotoxic $\mathrm{T}$ lymphocyte killing (CTL response). If $\mathrm{CD}^{+} \mathrm{T}$ cells do not function effectively, they allow the virus to escape immune control and cause the entire immune system to collapse. Virus-specific CTLs possess a range of antiviral activities, which vary in importance in different infections, including the ability to kill infected cells and to produce cytokines and chemokines [11].

The main immunopathological features of HIV infection include not only reduced numbers and impaired function of $\mathrm{CD}^{+} \mathrm{T}$ lymphocytes but also abnormal activation of the immune system. Abnormal activation of the immune system is defined as a state of abnormally elevated activation of the immune system, including lymphocyte subpopulations redistribution, cytokine expression disorders, cell dysfunction and abnormal cell death. Immune activation requires a series of processes such as cell activation, proliferation, apoptosis, and cytokine secretion. A variety of indicators can be used to reflect immune activation levels, such as the expression of activation markers by $\mathrm{T}$ cells, $B$ cells, and NK cells, and the levels of chemokines,




pre-inflammatory factors, and inflammatory factors in body fluids and lymph nodes [12]. At present, the ratio of CD38 and HLA-DR expression on the surface of T cells has been studied extensively, especially CD38. The prognostic value of T-cell activation increased when immune activation was assessed by co-expression of CD38 with HLA-DR [13] or CD45RO [14], suggesting expression of multiple markers on $\mathrm{T}$ cells could be indicative of a hyperactivation status. In the multicenter AIDS cohort study, CD38 expression was a better predictor of HIV disease progression than other markers of immune activation [15].

Studies [16] found that $\mathrm{CD} 4^{+} \mathrm{T}$ lymphocytes and $\mathrm{CD}^{+} \mathrm{T}$ lymphocytes continue to be chronically overactivated after HIV infection, and CD38 expression levels are significantly increased. The expression of CD38 may predispose $\mathrm{CD} 4^{+} \mathrm{T}$ cells to HIV infection and further enhance HIV replication $[17,18]$. As CD4 ${ }^{+} \mathrm{T}$ lymphocytes are depleted, the disease progresses, creating a cycle that suggests that lymphocyte activation and viral replication are mutually reinforcing (Fig. 1).

\section{The CD38 molecule}

\section{The distribution and function of the CD38 molecule}

Reinherz et al. [19] identified the CD38 molecule with a monoclonal antibody in the early 1980s. It was initially considered to be an activation antigen, mainly used for leukocyte classification and phenotypic identification. The gene encoding the human CD38 protein is localized to chromosome 4 . The CD38 gene is a single-copy gene that extends over $60 \mathrm{~kb}$, consisting of eight exons and seven introns. As research continued, it was found that the CD38 molecule is a single-chain type II transmembrane glycoprotein comprised of 300 amino acids with a molecular weight of $42-45 \mathrm{kDa}$, a 21 -amino acid cytoplasmic N-terminal domain, a 21-amino acid transmembrane domain, and a 258 amino acid extracellular catalytic and receptor domain [20]. The distribution of CD38 in cells is independent of cell type, but is related to the differentiation and activation state of the cell. The CD38 molecule is widely distributed, and its expression can be detected in peripheral blood $\mathrm{T}$ lymphocytes, $\mathrm{B}$ lymphocytes, natural killer cells (NK cells), and erythrocytes in healthy humans and in patients with a variety of acute and chronic diseases.

The expression of membrane CD38 can be modulated by certain physiological and pharmacological agents such as cytokines, retinoids, and lectins [21]. In all instances, these agents up-regulate CD38 expression independently of the cell lineage used. In myeloid leukemia cells, CD38 can be induced by retinoids [22, 23]. Cytokines, like IL-15, promotes expansion and survival of $\mathrm{CD} 38^{+} / \mathrm{CD}^{+}$
T cells [24]. This evidence supports that IL-15 may play a role in inducing CD38 expression.

The CD38 molecule has a broad and complex function. For example:

1) Enzyme activity [25]: CD38 was found to share sequence and structural homology with ADPR (ADPribosyl) cyclase as early as 1992 [26]. All ten cysteine residues in these two protein molecules are quite conserved, suggesting that they have similar secondary or tertiary structures. Therefore, it is speculated that CD38 should have ADP-ribosyl cyclase activity. It was observed that the $\mathrm{CD} 38$ protein molecule also possesses dehydrogenase activity that catalyzes the generation of ADPR from cADPR.

2) Receptor function: CD38 on the surface of the cell membrane has the characteristics of a receptor molecule [27]. Evidence of a receptor function of CD38 should include a well described ligand with a physiological role on defined $\mathrm{T}$ cell functions. It has been suggested that the ligand molecule of CD38 is CD31 $[28,29]$. CD31 can play a role similar to that of CD38 monoclonal antibody, and its binding to CD38 can cause the release of intracytoplasmic $\mathrm{Ca}^{2+}$ and the synthesis and secretion of cytokines.

3) Intercellular and intracellular signal transduction: for example, CD38 is involved in the co-stimulation of $\mathrm{T}$ lymphocytes and promotes the growth of $\mathrm{B}$ cells in the germinal center to avoid apoptosis [30], it regulates the maturation and differentiation of $\mathrm{B}$ cells [31], and it inhibits the growth of normal and leukemia myeloid progenitor cells [32]. Intracellular signal transmission can be accomplished by interacting with other molecular that have transmembrane signaling capabilities. It has been showed that CD38 is associated with TCR, BCR and CD16 of NK cells [33], and the common feature of these molecules is that they have specific signal transduction functions. However, previous experimental results have shown that CD38 can directly transmit signals through its cytoplasmic tail. Because CD38 is spatially related to the SH2 domain of lck through its cytoplasmic tail, and lck is a component of the intracytoplasmic signal chain [34].

4) Cell activation and cytokine production [35]: the combination of CD38 and competitive monoclonal antibodies can transmit activation signals, inducing the activation and proliferation of $\mathrm{T}$ cells and NK cells, and it can also mediate the production of IL-1, IL-6, IL-10, IFN- $\gamma$, TNF- $\alpha$, GM-CSF and other cytokines.

5) Adhesion activity [36]: Patterns of cell migration into tissue vary according to the level of expres- 
sion of CD38, indicating that CD38 is involved in cell-to-cell adhesion. CD4 ${ }^{+} \mathrm{CD} 45 \mathrm{RA}^{+} \mathrm{T}$ cells constitutively express low levels of CD38, which mainly migrate from the blood to the lymph nodes, whereas $\mathrm{CD}^{+}{ }^{+} \mathrm{CD} 45 \mathrm{RO}^{+} \mathrm{T}$ cells do not express CD38, and preferentially reach lymph nodes via peripheral tissues and the afferent lymph. Activated T cells express high levels of CD38 and tend to migrate to peripheral tissues. And CD38 was found to mediate weak adhesive interactions between leukocytes and human endothelial cells (HEC).

\section{The role of the CD38 molecule in HIV infection Early findings about the CD38 molecule}

The immune system responds rapidly to HIV infection, which results in reduced numbers and the impaired function of $\mathrm{CD}^{+} \mathrm{T}$ lymphocytes and abnormal activation of the immune system. Research on abnormal immune activation in HIV-infected patients has been proliferating since the 1990s. Early studies have suggested that the primary hallmark of immune activation in HIV-infected individuals is increased expression of the CD38 molecule on $\mathrm{T}$ cells, particularly memory $\mathrm{CD}^{+} \mathrm{T}$ cells. $\mathrm{CD}^{+}$ $\mathrm{T}$ lymphocytes play an important role in the antiviral response of the body. HIV can induce the formation of specific cytotoxic $\mathrm{CD}^{+} \mathrm{T}$ cells after entering the body, which can effectively control virus replication in the early stage of infection [10].

Since $\mathrm{CD}^{+} \mathrm{T}$ lymphocytes are the primary receptor cells that are attacked after HIV infection, a decrease in $\mathrm{CD}^{+}{ }^{+} \mathrm{T}$ cell counts and an increased viral load (number of HIV copies per milliliter of blood) are important signs of disease progression during HIV infection. During early HIV infection, the expression of the CD38 molecule is significantly increased. Using the density of CD38 expression on $\mathrm{T}$ cells as a measure of $\mathrm{T}$-cell abnormal activation, lymphocyte activation is one of the possible indirect mechanisms of $\mathrm{CD}^{+} \mathrm{T}$ lymphocyte depletion in HIV infection [16, 37, 38].

Currently, systemic chronic immune activation is considered as the driving force of $\mathrm{CD} 4{ }^{+} \mathrm{T}$-cell depletion and acquired immunodeficiency syndrome (AIDS). However, the causal link between these two phenomena has not been formally established. Binding of HIV to CCR5 or CXCR4 coreceptors on $\mathrm{CD}_{4}^{+} \mathrm{T}$ cells induces envmediated signals and activates $\mathrm{CD}^{+} \mathrm{T}$ cells by inducing expression of immune markers such as CD25, CD38, CD57, CD69, CD70, and HLA-DR. Activated CD4 cells release soluble factors, including cytokines, which in turn activate CD8 cells [39]. One mechanism by which generalized immune activation may damage the immune system is by providing available targets for HIV replication.
Indeed, activation, proliferation and differentiation of naïve and memory CD4 ${ }^{+} \mathrm{T}$ cells lead to increased CCR5 expression, making these cells more susceptible to infection. The concomitant presence of high levels of $\mathrm{CD}_{4}^{+}$ T-cell activation and a virus infecting and killing activated $\mathrm{CD}^{+} \mathrm{T}$ cells may help to sustain a vicious cycle, in which infection stimulates activation and activation stimulates infection, which may lead to a severe loss of $\mathrm{CD}^{+}{ }^{+} \mathrm{T}$ cells [17].

Studies suggested global activation of $\mathrm{T}$ cells may explain the more general immunologic dysregulation noted with HIV infection leading to high T-cell turnover, immune senescence, anergy, and finally cell death [12, 40-42]. T-lymphocyte activation is a hallmark of HIV infection that can lead to accelerated T-cell apoptosis $[43,44]$. Immune activation contributes more to CD4 decline than the direct effect of $\operatorname{HIV}[43,45,46]$. Thus, it is supported the concept that the pathogenic potential of $\mathrm{HIV}$ in a given individual is determined both by the level of viral replication and by the ability of a given virus in a given host to cause sustained increases in $\mathrm{CD}^{+} \mathrm{T}$-cell activation [47]. It has been confirmed that viral load is only an indirect contributor to the rate of progression to AIDS, that immune activation predicts changes in $\mathrm{CD}_{4}^{+}$ $\mathrm{T}$ cells stronger and independent of viral load, and that the effect of anti-retroviral therapy in increasing $\mathrm{CD}_{4}^{+} \mathrm{T}$ cell counts better correlates with the decrease in immune activation than the suppression of viral load [48-51].

Study [52] have shown that HIV-infected individuals with normal $\mathrm{CD}^{+}{ }^{+} \mathrm{T}$ cell counts tend to develop to the stage of AIDS more quickly if their CD38 expression levels are higher. In HIV-infected patients with low $\mathrm{CD}_{4}^{+}$ $\mathrm{T}$ cell levels, their condition can be maintained relatively stable if they have low levels of CD38 expression. This further suggests that the activation of $\mathrm{T}$ lymphocytes, on the one hand, contributes to viral multiplication and the expansion of $\mathrm{CD} 4^{+} \mathrm{T}$ cell infection, and, on the other hand, accelerates the destruction of $\mathrm{T}$ lymphocyte immune function.

In an earlier period, Liu et al. [53] suggested that the level of CD38 expression on the surface of $\mathrm{CD}^{+} \mathrm{T}$ cells could predict HIV infection progression and death, but that the level of expression was independent of the HIV viral load in the blood. As research progressed, it was demonstrated that the sustained stimulation of viral antigens after HIV infection in humans puts the immune system in an abnormally high state of activation, and the expression of CD38 on the surface of CD4 ${ }^{+} \mathrm{T}$ and $\mathrm{CD} 8^{+}$ $\mathrm{T}$ lymphocytes is abnormally elevated and correlates well with plasma viral load [54]. The CD38 molecule can not only reflect the activation status of the lymphocytes, but also reflects the viral load indirectly [13]. 


\section{The advent of the ART era}

Since the advent of ART (Antiretroviral Therapy), it has been proven to have positive effects on improving the immune responses, reducing the morbidity and mortality of HIV infected individuals [55], and improving the quality of life of patients [56]. At present, HIV-1 infected patients have a life expectancy that is only marginally shorter than that of HIV-uninfected individuals $[57,58]$. ART can suppress HIV replication, reduce the viral load and block viral replication $[55,59]$, restore $\mathrm{CD} 4^{+} \mathrm{T}$-cell numbers, reduce microbial translocation, inflammation, and aberrant T-cell activation $[60,61]$. The net effect of this is the near restoration of the immune system to preinfection status and control/prevention of opportunistic infections and other AIDS-associated ailments [62, 63].

It has been suggested that in untreated HIV-infected patients, a significantly elevated expression of CD38 on $\mathrm{CD}^{+} \mathrm{T}$ cells is indicative of a poor disease prognosis [64]. And effective antiretroviral therapy is associated with a significant decrease in abnormal immune activation $[65,66]$. It has been shown that ART treatment significantly reduces the $\mathrm{CD} 38^{+} / \mathrm{CD} 8^{+} \mathrm{T}$ lymphocytes ratio in HIV-infected patients [67].

A study observed the changes in the expression levels of CD38 on $\mathrm{CD} 4^{+} \mathrm{T}$ and $\mathrm{CD} 8^{+} \mathrm{T}$ cells in the naïve and memory subsets in $25 \mathrm{HIV}$-infected patients during antiretroviral therapy [68]. The results showed that after 12 months of treatment, the proportion of CD38 expression was reduced in all four cell subsets $\left(\mathrm{CD} 4^{+}\right.$memory cells, $\mathrm{CD} 4^{+}$naïve cells, $\mathrm{CD}^{+}$memory cells and $\mathrm{CD} 8^{+}$ naïve cells), and the magnitude of CD38 reduction in $\mathrm{CD}^{+} \mathrm{T}$ cells was significantly and positively correlated with the increase in $\mathrm{CD}_{4}^{+} \mathrm{T}$ cells. Another study tracked immune markers and viral load after one year of ART in HIV-infected patients, and the data suggested that an increased frequency of activated $\mathrm{CD} 38^{+} / \mathrm{CD}^{+} \mathrm{T}$ cells may contribute to reduced virologic suppression in patients receiving antiretroviral therapy, and that the percentage of $\mathrm{CD}^{2} 8^{+} / \mathrm{CD}^{+} \mathrm{T}$ cells was negatively, although not significantly, correlated with the CD4:CD8 ratio [69]. It has been suggested that a persistently low CD4:CD8 ratio during long-term effective antiretroviral therapy in HIV-infected patients represents persistent immune dysfunction, which predicts a high risk of non-AIDS morbidity and mortality [70].

Based on various studies in previous years, it has been suggested in recent years that the analysis of circulating $\mathrm{CD}_{3}{ }^{+} \mathrm{T}$ lymphocyte frequency may become a complementary tool that can be used as a laboratory indicator for monitoring HIV infection trends and treatment response [71-73]. Primary HIV infection (PHI) is the period when the virus begins to replicate rapidly, immediately after an individual is exposed to HIV, and there is a massive increase in the virus in the blood during this period. The viral load is subsequently controlled by the immune system and drops to a modulation point, which is an important indication of the subsequent decline of $\mathrm{CD}^{+} \mathrm{T}$ cells and the development of HIV infection [37]. PHI triggers a strong activation of the immune system [74]. A study tested the expression of CD38 on $\mathrm{CD} 4^{+}$ and $\mathrm{CD}^{+} \mathrm{T}$ cells from patients with $\mathrm{PHI}$ and found that the proportion of the expression of the CD38 molecule at this time is also an important prognostic parameter for the disease and may be related to disease progression [75]. Appay et al. [76] suggested that the timing of initiating antiretroviral therapy during PHI may be critical in reducing the level of immune activation, which has been confirmed in other studies [77]. Early initiation of antiretroviral therapy during the acute infection phase (Fiebig I/II) can reduce activation markers (percentage

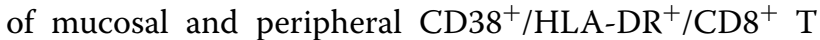
cells) to the levels observed in uninfected individuals. This study demonstrated that initiation of ART in Fiebig I/II completely reversed the initial mucosal and systemic immune activation, whereas patients treated after the acute infection maintained higher mucosal and systemic $\mathrm{CD}^{+}{ }^{+} \mathrm{T}$-cell activation after ART initiation. Thus, the timing of initiating treatment during the primary infection is critical for reducing abnormal immune activation levels and may directly affect patient prognosis.

Using the proportion of cells with abnormal immune activation as an indicator of clinical assessment may help in making an early judgment about the HIV-infected patient's response to treatment [78]. The level of CD38 expression affects immune reconstitution after antiretroviral therapy. The magnitude of reduction in the proportion of CD38 expression early in treatment was a predictor of treatment effect. Patients with greater reductions in the proportion of CD38 expression two weeks after the start of treatment took less time to achieve complete viral suppression [79].

Depending on whether they are receiving cART (combined antiretroviral therapy), in HIV-infected patients, $\mathrm{CD} 8^{+} \mathrm{T}$ lymphocytes display different phenotypic and functional responses [80]. Although the CD38 molecule in the peripheral circulation exhibits abnormally elevated levels in T lymphocytes from HIV-infected patients who did or did not receive cART, $\mathrm{CD} 38^{+} / \mathrm{CD}^{+} \mathrm{T}$ cells from patients who have already received cART have a higher IL-7 reactivity, which leads to STAT-5 phosphorylation and protection against apoptosis. These changes were not observed in patients who did not receive cART. Such results suggest that cART has a positive effect on the in vivo homeostasis of $\mathrm{CD} 38^{+} \mathrm{T}$ lymphocytes. 


\section{HICs (HIV controllers) and EUs (HIV-exposed uninfected individuals)}

Individuals vary in their susceptibility to HIV infection, and a small number of HIV-infected individuals can spontaneously control the replication of the virus, a group known as "HIV Controllers" (HICs). HICs usually have relatively high $\mathrm{CD}^{+} \mathrm{T}$ cell counts and maintain a viral load below the threshold of detection by conventional assays for many years without antiretroviral therapy [81]. The HIC status is related to a variety of factors, including viral defects, cellular factors, and innate immune factors [82], but it is mostly believed that $\mathrm{T}$ cells (especially HIV-specific CD8 ${ }^{+} \mathrm{T}$ cells) play a major role.

As we all know, HICs produce a unique type of $\mathrm{CD}^{-} 8^{-} /$ $\mathrm{HLA}^{-D R^{+}} / \mathrm{CD}^{+} \mathrm{T}$ lymphocytes. HICs have been shown to possess $\mathrm{HIV}$-specific $\mathrm{CD}^{+} \mathrm{T}$ cells capable of inhibiting in vitro HIV replication [83, 84]. Although HIVspecific $\mathrm{CD}^{+} \mathrm{T}$ cells typically express similar levels of two activation markers, CD38 and HLA-DR, and they correlate with viral load in non-HICs [85], they exhibit a unique CD38 low expression, HLA-DR high expression activation phenotype in HICs $[83,86]$. The CD38 ${ }^{-}$/ $\mathrm{HLA}^{-\mathrm{DR}^{+}}$phenotype may reflect low levels of activation and thus may contribute to the maintenance of the HIC status [37, 83, 86]. HICs have fewer immune alterations and effector mechanisms (mainly in the peripheral blood) associated with viral control compared to normal progressives. A study exploring the immune properties of gut-associated lymphoid tissue (GALT), the primary target of infection, evaluated the frequency and activation phenotype of T cells in GALT samples from 11 HICs and 15 HIV progressives and showed that T cells in GALT of HICs express HLA-DR but not CD38 [87]. These studies suggest that loss of CD38 expression appears to be associated with better viral control and delayed progression to AIDS.

Another group of individuals who are exposed to HIV but are uninfected are known as HIV-exposed uninfected individuals (EUs) [88], and these individuals have complex antiviral mechanisms in their bodies. These EUs are from different high-risk populations such as sex workers, healthcare workers, hemophiliacs receiving HIV-infected blood, drug users, children of HIV-infected mothers, and individuals in stable relationships with HIV-infected people [88-90]. EUs share the same features as HICs in that both types of $\mathrm{T}$ lymphocytes have reduced expression of CD38 [91].

We both observed the HIV-specific $\mathrm{CD}^{+} \mathrm{T}$ cells lacking CD38 expression, often along with HLA-DR high expression in HICs and EUs. The low expression of CD38 may reflect the lack of general immune activation, and the expression of HLA-DR may actually characterize T cells with high proliferative potential [83]. This differential expression might be linked to a superior capacity to respond to antigenic stimulation in the absence of nonspecific activation driven by the inflammatory context present in viremic patients, which may associated with better viral control and delayed progression to AIDS.

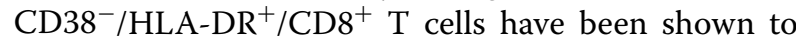
effectively suppress viral replication in autologous $\mathrm{CD} 4^{+}$ $\mathrm{T}$ cells by eliminating $\mathrm{HIV}$-infected cells without the need for exogenous stimulation [83]. This suppressive capacity is not observed in either viremic progressors or in HAART-treated patients and has been associated with an effective loading of perforin and granzyme B in $\mathrm{CD}^{+} \mathrm{T}$ cells from controllers upon contact with HIVinfected cells [92, 93]. The upregulation of perforin and granzyme B may be related to high levels of expression of the T-box transcription factor T-bet after the in vitro expansion of $\mathrm{HIV}$-specific $\mathrm{CD}^{+} \mathrm{T}$ cells [94]. The rapid elimination of infected cell targets by ex vivo $\mathrm{CD} 8^{+} \mathrm{T}$ cells implies the presence of CTLs with immediate effector functions. Consistent with these results, differentiated effector $\mathrm{CD}^{+} \mathrm{T}$ cells directed against HIV-1 are found more frequently in $\mathrm{HICs}$ compared to HIV-1 progressors $[83,95]$.

The ability of viral control of CD38 $8^{-} / \mathrm{HLA}_{-} \mathrm{DR}^{+} / \mathrm{CD}^{+}$ $\mathrm{T}$ cells is highly correlated with the anti-Gag response, not with Nef- or Env-specific responses [84, 86, 96, 97], which is consistent with earlier studies reporting an association between the anti-Gag $\mathrm{CD}^{+} \mathrm{T}$-cell response and viral control $[98,99]$. Several studies suggest that Gagspecific CTLs from HICs mediate effective viral control because of their higher functional avidity, that is, the ability to react to lower antigen concentrations and to recognize more epitope variants than those from HIV progressors $[100,101]$. A direct contribution to the control of the viral reservoir by the Gag-specific $\mathrm{CD}^{+} \mathrm{T}$-cell response in HICs is suggested by their association with a low HIV reservoir in the central memory CD4 ${ }^{+} \mathrm{T}$ cells of HICs carrying HLA-B57/27 alleles [102].

It has been demonstrated that $\mathrm{CD}^{-} 8^{-} / \mathrm{HLA}^{-} \mathrm{DR}^{+}$cells are characterized by low expression, high viability, proliferative capacity and high cytotoxicity in vitro compared to $\mathrm{CD}^{+} 8^{+} / \mathrm{HLA}^{-\mathrm{DR}^{+}}$cells, and that $\mathrm{CD} 38^{-} / \mathrm{HLA}^{-\mathrm{DR}^{+}}$ cells are preferentially generated at low viral antigen concentrations [103]. Induction of this protective CD8 ${ }^{+}$ subtype may be critical for HIV vaccine development. A separate study has found that CD38 is highly expressed in central memory CD4 ${ }^{+} \mathrm{T}$ cells in HIV-infected patients receiving ART for more than 5 years [104], which we know may play an important role in the long-term presence of HIV in the body. The findings of this study suggest that memory $\mathrm{CD} 38^{+} / \mathrm{CD}^{+} \mathrm{T}$ cells perpetuate the virus in $\mathrm{HIV}$-infected patients receiving long-term ART, 
which may provide a potential target for addressing the persistence of HIV in humans.

\section{Infected children and pregnant women}

In a series of previous studies, it was not difficult to conclude that increased levels of $\mathrm{CD} 38^{+} / \mathrm{CD}^{+} \mathrm{T}$ cells in adults are a strong indicator of disease progression after HIV infection. However, some studies have found conflicting data in children with HIV infection. Freguja and colleagues [105] reported a study that evaluated the relationship between viral load and immune activation in HIV-1-infected children. The study showed a strong relationship between viral load and immune activation, suggesting that viral load induces a rise in immune activation. Romeiro et al. [106] found that a higher percentage of activated $\mathrm{CD} 8^{+} \mathrm{T}$ cells was present in all HIVinfected children regardless of disease progression, and that $\mathrm{CD} 8^{+} \mathrm{T}$ cell activation was not associated with the viral load or the percentage of $\mathrm{CD} 4^{+} \mathrm{T}$ cells. Therefore, it was concluded that the expression of CD38 in CD8 $8^{+}$lymphocytes from HIV vertically infected children was not associated with disease progression, and these immunological parameters could not be applied to the prognostic assessment. The view of this study is contrary to that of studies in adult HIV-infected individuals, and it is speculated that it may be related to the immature immune system in children, for reasons that will require more direct studies to show. It has been reported that CD38 is expressed early in hematopoietic cells, with downregulation during the cell maturation process and re-expression upon cell activation. This cyclic nature of CD38 expression during lymphopoietic ontogeny may explain the expression of CD38 in HIV-infected children [106].

And in children accepted ART, immune reconstitution is different from that in adults. It involves mainly naïve cells, due probably to more efficient thymopoiesis, and some children have a gain in CD4 cells despite persistent detectable viraemia [107-109]. Persistence of chronic immune activation has been described in children with such a discordant response to ART. In children with this discordant response to therapy, there is a persistence or even an increase in immune activation [110].

The previous study shown that the total $\mathrm{CD}^{+}$lymphocytes may not be altered by pregnancy, but activated $\mathrm{CD}^{+} \mathrm{T}$ lymphocyte counts in HIV-positive pregnant women $\left(\mathrm{CD}^{2} 8^{+} / \mathrm{CD}^{+}{ }^{+} \mathrm{T}\right.$ and HLA-DR ${ }^{+} / \mathrm{CD}^{+} \mathrm{T}$ lymphocytes) were found to be lower than in HIV-positive women who were not pregnant, and the counts were also reduced in the second and third trimesters [111]. Based on this study, it can be inferred that pregnancy has a significant inhibitory effect on $\mathrm{CD}^{+} \mathrm{T}$ lymphocytes immune activation during HIV infection.
Another study shown that pregnancy contributes to the activation of peripheral $\mathrm{CD} 8^{+} \mathrm{T}$ cells and increase in pro-inflammatory cytokines [112]. Immune activation has been documented in both pregnant and non-pregnant HIV-infected women [113-116]. In a 2017 paper in Nature Reviews Immunology, Mor et al. [117] described the occurrence of three normal successive immunological stages during gestation. They further proposed in this same paper that inflammation induced by HIV infection could disrupt this ordered sequence and increase the risk of fetal damage and premature birth. Studies have shown that the heightened immune activation observed in pregnant HIV infected women resulted from the combined effects of both pregnancy and HIV-mediated inflammation, which in turn promoted higher HIV viral loads [113, $116]$.

\section{AIDS complications and co-infections}

HIV attacks the immune system throughout the body and can cause numerous complications in various parts of the body. For example, HIV can cross the blood-brain barrier and may lead to HIV-associated neurocognitive disorders (HAND) [118]. In some patients with HIVassociated neurocognitive deficits (HAND), astrocyte surface levels of CD38 are significantly elevated [119], presumably regulated through the MAPK signaling pathway and the transcription factor NF- $\mathrm{kB}$. Using HIV-RNA (VL) 20 copies $/ \mathrm{ml}$ as a cut-off value to distinguish viremia from non-viremia, a study found that CD38 expression of $\mathrm{CD}^{+} \mathrm{T}$ lymphocytes or $\mathrm{CD}^{+} \mathrm{T}$ lymphocytes in both peripheral blood and cerebrospinal fluid was different between the two groups. The $\mathrm{T}$ cell activation/apoptosis markers in the cerebrospinal fluid were negatively correlated with the central nervous system permeability score (CPE), suggesting its importance for restoring immune function therapy [120]. These findings suggest that CD38 is a potential marker to distinguish between two patient subgroups, with and without cerebrospinal fluid viremia.

The finding of an elevated percentage of circulating $\mathrm{CD}^{+} 8^{+} \mathrm{T}$ cells should warrant clinicians to consider the possibility of the transmission of HIV infection to the nervous system in order to intervene earlier to prevent progression. In addition, in patients with oral lesions due to HIV infection [121], median CD38 levels on the surface of $\mathrm{T}$ lymphocytes in peripheral blood were found to be significantly higher in patients with oral mucosal lesions than in patients without oral lesions, and median CD38 levels were also significantly higher in patients with gingivitis and periodontitis, suggesting that elevated CD38 expression levels in peripheral blood in HIV-positive patients are associated with oral lesions.

Significantly elevated expression of CD38 was observed in both $\mathrm{CD} 4^{+}$and $\mathrm{CD} 8^{+} \mathrm{T}$ cells in HIV/HCV co-infected 
patients compared to mono-infected patients and healthy controls. There was a direct correlation between the expression of $\mathrm{CD} 38$ in $\mathrm{CD} 4^{+} \mathrm{T}$ cells and $\mathrm{CD} 8^{+} \mathrm{T}$ cells, suggesting a synergistic increase in the level of immune activation in both T cell subsets. Despite effective mediation of HIV suppression by ART, HIV/HCV co-infected patients still have high expression levels of CD38. When HCV replication was suppressed by IFN- $\alpha$ and ribavirin treatment, CD38 expression was decreased, suggesting that immune activation is also associated with a high HCV viral load in co-infected patients [122]. However, in another study [123], it was found that in $\mathrm{HIV} / \mathrm{HCV}$ co-infected patients, HIV plays a key role in determining host immune activation, whereas the role of $\mathrm{HCV}$ needs further investigation.

\section{Expression of the CD38 molecule in other diseases}

In addition to co-infection, similar results have been reported in other types of viral infections, such as HBV infection [124]. It was found that $\mathrm{CD}^{+} \mathrm{T}$ cell counts and $\mathrm{CD}^{+}{ }^{+} \mathrm{T}$ cell counts in the peripheral blood were decreased and that the proportion of $\mathrm{CD}^{+} 8^{+} / \mathrm{CD}^{+} \mathrm{T}$ cells was increased in patients with chronic hepatitis B, which was significantly higher than in HBV carriers and healthy controls. In patients with hepatitis B treated with and responding effectively to adefovir, the proportion of $\mathrm{CD} 38^{+} / \mathrm{CD}^{+} \mathrm{T}$ cells decreased significantly, accompanied by a decrease in viral load. $\mathrm{CD} 38^{+} / \mathrm{CD} 8^{+} \mathrm{T}$ cell counts fluctuated more in patients who failed to respond to treatment. This study demonstrates that abnormally activated $\mathrm{CD}^{+} \mathrm{T}$ cells in chronic $\mathrm{HBV}$ infection can be partially reversed by antiretroviral therapy. Measuring the expression level of CD38 and other molecules on PBMC in HBV-infected patients helps to objectively reflect the state of cellular immune function in these patients, and at the same time, has a certain reference value for the patient's disease regression and the judgment of the treatment effect.

CD38 also plays an auxiliary role in the assessment of malignant tumor disease and prognosis. It has been shown that the expression of CD38 in epithelial ovarian cancer (EOC) is higher than in normal tissues, and high CD38 levels are associated with prolonged disease-free survival and a significant increase in overall patient survival [125]. CD38 contributes to the regulation of antitumor immunity and can be used as a prognostic biomarker and potential immunotherapeutic target, which suggests a potential application of CD38 as a tumor marker.

Several hematologic malignancies also express varying levels of CD38 [126-128], such as multiple myeloma (MM), chronic lymphocytic leukemia (CLL), non-Hodgkin's lymphoma (NHL), acute lymphoblastic leukemia
(ALL), and acute myeloid leukemia (AML). In hairy cell leukemia, elevated levels of CD38 expression are a marker of a poor prognosis [129], and CLL patients with high CD38 expression also have more aggressive clinical behaviors and a less optimistic prognosis [130]. A study [131] analyzed the CD38 expression levels of acute T-lymphocytic leukemia in children and showed that 97.9\% of T-ALL patients were positive for CD38, and T-ALL patients had significantly higher CD38 expression than B-ALL and AML patients. The high CD38 expression group had a worse early treatment response than the low CD38 expression group. Other studies have suggested that CD38 is only minimally expressed on normal lymphocytes or bone marrow cells, but is highly expressed on the surface of myeloma cells, so the CD38 molecule may be a new target for MM therapy [132, 133].

The CD38 molecule has also been associated with the development of several autoimmune diseases. The reason for this may be that it catalyzes the metabolism of two calcium messengers, cyclic adenosine diphosphate ribose (cADP) and nicotinic acid adenine dinucleotide phosphate (NAADP), which are involved in intracellular calcium signaling and the modulation of immune cell function [134]. For example, CD38 is highly expressed in the blood, $\mathrm{CD}^{+}$and $\mathrm{CD} 56^{+}$subpopulations of patients with rheumatoid arthritis, and the percentage of CD38 ${ }^{+}$ cells is significantly correlated with RF levels [135]. Therefore, some researchers have suggested that CD38 may be a potential target for RA disease blockade [136].

\section{Future perspectives}

As the research proceeds further, increasing numbers of researchers are suggesting that abnormal immune activation may be an important factor in mediating immunodeficiency and disease progression, independent of HIV replication. Since CD38 expression is intrinsically correlated with $\mathrm{CD}_{4}^{+} \mathrm{T}$ cell counts, but independent of whether $\mathrm{CD} 8^{+}$lymphocytes are in a circulating state, it may be important to suggest that CD38 expression is independent of the cell cycle and thus may itself be involved in pathogenic mechanisms [137]. Whether markers of immune cell activation, particularly the CD38 molecule [38], reflect or participate in other processes leading to HIV infection progression, remains to be elucidated. Even though CD38 expression is highly correlated with $\mathrm{T}$ cell activation, its function in this process is still not fully understood.

The expression of CD38 on T cells strongly predicts the risk of HIV infection progression, but it is not known whether CD38 is a marker or receptor for immune dysfunction. The CD38 molecule has strong immunomodulatory functions [138]. Soluble CD38-regulated dendritic cells produce IL-10 and TGF- $\beta$, thereby decreasing the 
cellular immune activity of CD4 ${ }^{+}$lymphocytes [139]. Based on these findings about the CD38 molecule, most investigators believe that sustained immune activation of $\mathrm{CD}^{+} \mathrm{T}$ cells may be a marker of progression of HIV infection [111]. Many investigators have suggested that CD38 on $\mathrm{CD}^{+} \mathrm{T}$ cells alone predicts HIV infection progression independent of viral load and $\mathrm{CD}_{4}^{+} \mathrm{T}$ cell count, but others have suggested that the marker itself is not sufficiently sensitive or specific [140].

However, in previous studies, we learned that CD38 is enzymatically active and it is a well-known exonuclease that catalyzes the conversion of nicotinamide-adenine dinucleotide (NAD) to ADPR, cADPR, and NAADP. These "second messengers" can regulate $\mathrm{T}$ cell function. Several studies [141-144] concluded that the relationship between CD38 and the development of HIV infection might be attributable to the enzyme activity of CD38.

Juan et al. [145] also suggested that the possible mechanism of $\mathrm{CD}^{+} \mathrm{T}$ cell depletion was due to the enzymatic activity of CD38. These researchers found that increased CD38 catalytic activity may reduce cytoplasmic NAD in $\mathrm{CD}^{+} \mathrm{T}$ cells, leading to a chronic Warburg effect (i.e., aerobic glycolysis). This metabolic state was discovered by Warburg in malignant tumor cells in 1956, and it is essentially a marked enhancement of glycolytic pathways under aerobic conditions, as evidenced by increased glucose uptake and increased lactate production [146], which would reduce mitochondrial function.

At the same time, ADPR and cADPR, as catalytic products of CD38, can activate calcium channels and increase cytoplasmic $\mathrm{Ca}^{2+}$ concentrations, further reducing mitochondrial integrity and thereby reducing $\mathrm{CD}^{+} \mathrm{T}$ cell viability and regenerative capacity. Chronic increased activity of $\mathrm{CD} 38$ in the memory $\mathrm{CD} 4^{+} \mathrm{T}$ cell environment may increase NAD conversion, leading to cytoplasmic NAD depletion, which in turn can promote the Warburg effect and affect mitochondrial function and integrity. In addition, elevated concentrations of cytoplasmic $\mathrm{Ca}^{2+}$ would further increase mitochondrial stress, ultimately leading to decreased survival of $\mathrm{CD} 4^{+} \mathrm{T}$ cells (Fig. 2).

If the above hypothesized pathogenic mechanism which kills $\mathrm{CD} 4^{+} \mathrm{T}$ cells independently of viral infection can be proven experimentally, it will reveal new therapeutic targets that may be used as a strategy for antiretroviral therapy in the future.

In fact, abnormal immune activation has emerged as a potential therapeutic target. Researchers have attempted to reduce activation levels by applying

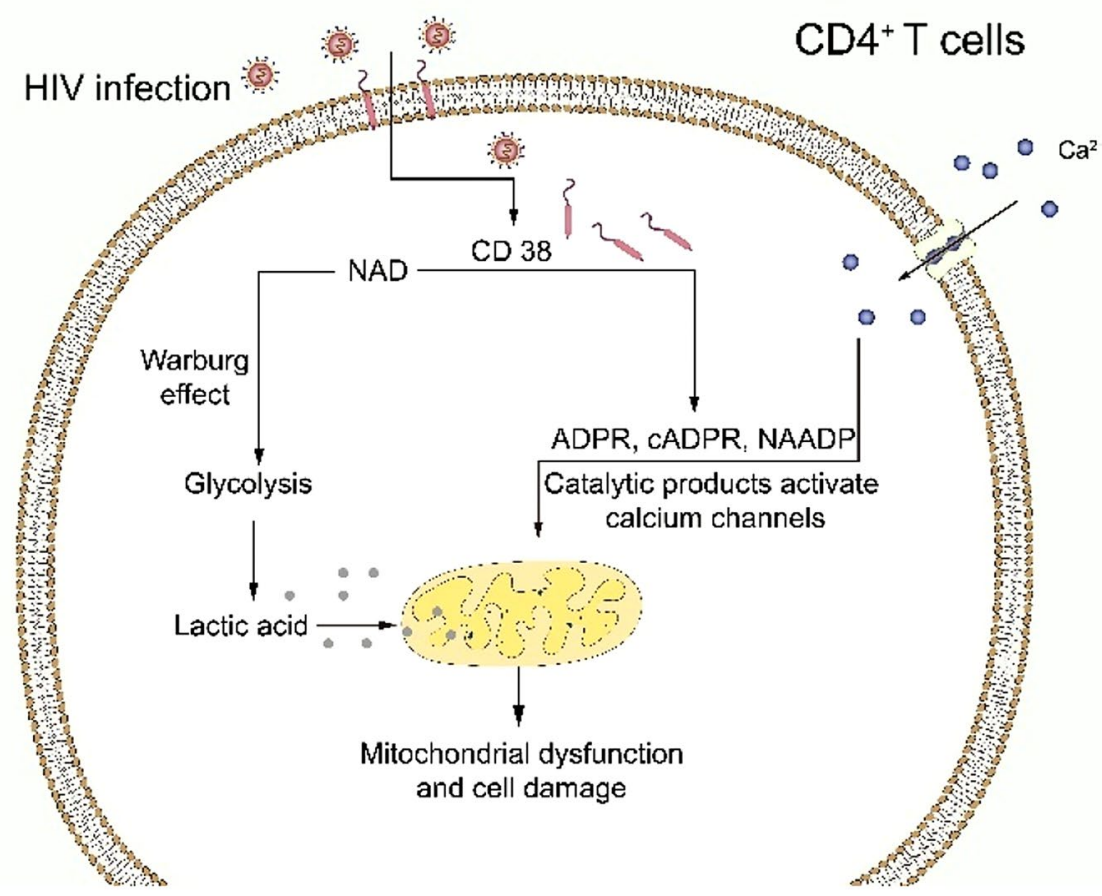

Fig. 2 Enzymatic activity of CD38 molecules leads to internal alterations in $C D 4^{+} T$ cells. CD38 catalyzes the conversion of NAD to ADPR, CADPR, and NAADP, which reduces cytoplasmic NAD in $C D 4^{+} T$ cells, leading to a chronic Warburg effect that decreases mitochondrial function. The catalytic products of CD38 can activate calcium channels and increase cytoplasmic $\mathrm{Ca}^{2+}$ concentrations, further reducing mitochondrial integrity. Depletion of cytoplasmic NAD promotes the Warburg effect and continues to affect mitochondrial function and integrity. Elevated cytoplasmic $\mathrm{Ca}^{2+}$ concentrations further increase mitochondrial stress, which ultimately leads to decreased $\mathrm{CD} 4^{+} \mathrm{T}$ cell survival 
immunosuppressive agents or modulators in order to reduce immune damage [147]. However, since most clinical trials aimed at reducing aberrant immune activation only included a limited number of patients or showed effects on immune activation biomarkers only, these studies have not been able to assess any impact of suppressing or reducing immune activation levels on clinical outcomes.

AIDS caused by HIV infection is a disease of the immune system. The CD38 molecule acts as a transmembrane glycoprotein on the cell surface and it is closely related to the development of several diseases. CD38 is barely expressed on the surface of lymphocytes in HIVnegative adults. CD38 has been widely recognized as a potential prognostic marker for HIV-positive individuals prior to antiretroviral therapy (ART) and its expression level predicts a downward trend in viral load after initiation of therapy. The detection of CD38 provides a reliable real-time complementary test for long-term viral load monitoring in HIV-infected patients [148]. However, the mechanism of the CD38 molecule in HIV infection has been poorly reported and needs to be further investigated in view of the broad and complex role of this cell surface molecule.

\section{Conclusion}

The expression of the CD38 molecule is widely distributed, and its presence in cells is related to their differentiation and activation state. The expression of CD38 can be detected in T-lymphocytes, B-lymphocytes, natural killer cells (NK cells) and erythrocytes in the peripheral blood of healthy humans or patients with various acute/chronic diseases [21]. The functions of the CD38 molecule are extensive and complex, including enzyme activity, intercellular signal transduction, cell activation, cytokine production, receptor function and adhesion activity [149]. After HIV infection, T lymphocytes continue to be chronically over-activated, and the expression level of CD38 is significantly increased. CD38 not only reflects the activation status of lymphocytes but also indirectly reflects the viral load. ART significantly reduces the proportion of CD38-positive lymphocytes in HIV-infected patients, and its count and percentage reflect the viral load in the body, which is an indicator of the antiviral effect of the treatment [150]. The results of this review suggest that CD38 is not only an indicator of elevated post-infection, but also an active player in HIV-1 infection. To sum up, expression of CD38 may predispose cells to HIV infection and further enhance HIV replication. With the depletion of $\mathrm{CD}^{+}{ }^{+} \mathrm{T}$ lymphocytes, the disease continues to progress, creating a vicious cycle. However, the knowledge about CD38 in HIV infection is currently inconclusive as to whether it is a player independent of viral replication that mediates immunodeficiency and disease progression or is a by-product of $\mathrm{T}$ cell activation.

Various studies have proven the necessity and feasibility of using the CD38 molecule as a research object in HIV infection research. It is believed that with indepth research using the CD38 molecule as the target, we can further understand the series of changes in the body after HIV infection, or further reveal the pathogenesis of HIV infection, and contribute to the development of a vaccine or find new treatment methods.

\section{Abbreviations \\ ALL: Acute lymphoblastic leukemia; AML: Acute myeloid leukemia; ADPR: Adenosine diphosphate ribose; AIDS: Acquired immune deficiency syndrome; ART: Antiretroviral treatment; BCR: B cell receptor; CADPR: Cyclic adenosine diphosphate ribose; CART: Combined antiretroviral therapy; CD: Cluster of differentiation; CPE: Central nervous system permeability score; CLL: Chronic lymphocytic leukemia; CADP: Cyclic adenosine diphosphate ribose; CTL: Cytotoxic T Iymphocyte; EOC: Epithelial ovarian cancer; EUs: HIV-exposed uninfected individuals; GM-CSF: Granulocyte macrophage-colony stimulat- ing factor; GALT: Gut-associated lymphoid tissue; HBV: Hepatitis B virus; HCV: Hepatitis C virus; HEC: Human endothelial cells; HICs: HIV controllers; HIV: Human immunodeficiency virus; HAND: HIV-associated neurocognitive disor- ders; HLA: Human leukocyte antigen; IFN-ץ: Interferon-gamma; IL: Interleukin; MM: Multiple myeloma; NK: Natural killer cells; NAD: Nicotinamide-adenine dinucleotide; NAADP: Nicotinic acid adenine dinucleotide phosphate; NHL: Non-Hodgkin's lymphoma; PHI: Primary HIV infection; RF: Rheumatoid factor; TCR: T cell receptor; TGF- $\beta$ : Transforming growth factor-beta; TNF-a: Tumor necrosis factor-alpha.}

\section{Acknowledgements}

The authors would like to thank Ling Jiang, Tianhong Guo, Yuhan Wang, Li Yang and Xingquan Zhao for their valuable advice, and to acknowledge the people living with HIV who have participated in, and contributed to, the body of research referenced in this review.

\section{Authors' contributions}

LQL and JW carried out literature search and acquisition of references. LQL, JW QY and XQX were involved in the conception and design of the manuscript. YSH performed manuscript review and gave final approval of the version to be published. All authors have read and approved the final manuscript.

\section{Funding}

This study was supported by the Office of Science and Technology of Luzhou [Grant Number 2017LZXNYD-J23].

Availability of data and materials

Not applicable.

\section{Declarations}

Ethics approval and consent to participate

Not applicable.

\section{Consent for publication}

Not applicable.

\section{Competing interests}

The authors declare that they have no competing interests.

\section{Author details}

${ }^{1}$ Department of Transfusion, The Affiliated Hospital of Southwest Medical University, 25 Taiping Road, Luzhou, Sichuan 646000, People's Republic of China.

2 Department of Clinical Laboratory, The First People's Hospital of Longquanyi 
District, Chengdu, 201 Third Yihe Group, Longquanyi District, Chengdu, Sichuan 610100, People's Republic of China.

\section{Received: 18 October 2020 Accepted: 6 March 2021} Published online: 05 April 2021

\section{References}

1. Savarino A, Bottarel F, Malavasi F, Dianzani U. Role of CD38 in HIV-1 infection: an epiphenomenon of T-cell activation or an active player in virus/host interactions? AIDS. 2000;14(9):1079-89.

2. McCune JM. The dynamics of CD4+ T-cell depletion in HIV disease. Nature. 2001;410(6831):974-9.

3. Maartens G, Celum C, Lewin SR. HIV infection: epidemiology, pathogenesis, treatment, and prevention. Lancet. 2014;384(9939):258-71.

4. Bernstein HB, Wang G, Plasterer MC, Zack JA, Ramasastry P, Mumenthaler SM, et al. CD4+ NK cells can be productively infected with HIV, leading to downregulation of CD4 expression and changes in function. Virology. 2009;387(1):59-66.

5. Chen NC, Partridge AT, Sell C, Torres C, Martín-Garcia J. Fate of microglia during HIV-1 infection: from activation to senescence? Glia. 2017;65(3):431-46.

6. Yaseen MM, Abuharfeil NM, Yaseen MM, Shabsoug BM. The role of polymorphonuclear neutrophils during HIV-1 infection. Arch Virol. 2018;163(1):1-21.

7. Moir S, Malaspina A, Ogwaro KM, Donoghue ET, Hallahan CW, Ehler LA, et al. HIV-1 induces phenotypic and functional perturbations of B cells in chronically infected individuals. Proc Natl Acad Sci U S A. 2001;98(18):10362-7.

8. Scadden DT, Shen H, Cheng T. Hematopoietic stem cells in HIV disease. J Natl Cancer Inst Monogr. 2001;28:24-9.

9. Douek DC, Picker LJ, Koup RA. T cell dynamics in HIV-1 infection. Annu Rev Immunol. 2003;21:265-304.

10. Benito JM, López M, Soriano V. The role of CD8+T-cell response in HIV infection. AIDS Rev. 2004;6(2):79-88.

11. McMichael AJ, Rowland-Jones SL. Cellular immune responses to HIV. Nat Aust. 2001;410(6831):980-7.

12. Appay $V$, Sauce D. Immune activation and inflammation in HIV-1 infection: causes and consequences. J Pathol. 2008;214(2):231-41.

13. Benito JM, López M, Lozano S, Martinez P, González-Lahoz J, Soriano V. CD38 expression on CD8 T lymphocytes as a marker of residual virus replication in chronically HIV-infected patients receiving antiretroviral therapy. AIDS Res Hum Retroviruses. 2004;20(2):227-33.

14. Bofill M, Mocroft A, Lipman M, Medina E, Borthwick NJ, Sabin CA, et al. Increased numbers of primed activated CD8+CD38+CD45RO+T cells predict the decline of CD4+ T cells in HIV-1-infected patients. AIDS. 1996;10(8):827-34.

15. Liu Z, Cumberland WG, Hultin LE, Prince HE, Detels R, Giorgi JV. Elevated CD38 antigen expression on CD8+ T cells is a stronger marker for the risk of chronic HIV disease progression to AIDS and death in the Multicenter AIDS Cohort Study than CD4+ cell count, soluble immune activation markers, or combinations of HLA-DR and CD38 expression. J Acquir Immune Defic Syndr Hum Retrovirol. 1997;16(2):83-92.

16. Paiardini M, Müller-Trutwin M. HIV-associated chronic immune activation. Immunol Rev. 2013;254(1):78-101.

17. Douek DC, Brenchley JM, Betts MR, Ambrozak DR, Hill BJ, Okamoto $Y$, et al. HIV preferentially infects HIV-specific CD4+ T cells. Nature. 2002:417(6884):95-8.

18. Gougeon ML, Lecoeur H, Dulioust A, Enouf MG, Crouvoiser M, Goujard $C$, et al. Programmed cell death in peripheral lymphocytes from HIVinfected persons: increased susceptibility to apoptosis of CD4 and CD8 $T$ cells correlates with lymphocyte activation and with disease progression. J Immunol. 1996:156(9):3509-20.

19. Reinherz EL, Kung PC, Goldstein G, Levey RH, Schlossman SF. Discrete stages of human intrathymic differentiation: analysis of normal thymocytes and leukemic lymphoblasts of T-cell lineage. Proc Natl Acad Sci U S A. 1980;77(3):1588-92.

20. Lee HC. Structure and enzymatic functions of human CD38. Mol Med. 2006:12(11-12):317-23.
21. Mehta K, Shahid U, Malavasi F. Human CD38, a cell-surface protein with multiple functions. FASEB J. 1996;10(12):1408-17.

22. Drach J, McQueen T, Engel H, Andreeff M, Robertson KA, Collins SJ, et al. Retinoic acid-induced expression of CD38 antigen in myeloid cells is mediated through retinoic acid receptor-alpha. Cancer Res. 1994;54(7):1746-52

23. Mehta K, McQueen T, Manshouri T, Andreeff M, Collins S, Albitar M. Involvement of retinoic acid receptor-alpha-mediated signaling pathway in induction of CD38 cell-surface antigen. Blood. 1997;89:3607-14.

24. Bahri R, Bollinger A, Bollinger T, Orinska Z, Bulfone-Paus S. Ectonucleotidase CD38 demarcates regulatory, memory-like CD8+ T cells with IFN- $\gamma$-mediated suppressor activities. PLoS ONE. 2012;7(9):e45234.

25. Lund FE, Yu N, Kim KM, Reth M, Howard MC. Signaling through CD38 augments $B$ cell antigen receptor (BCR) responses and is dependent on BCR expression. J Immunol. 1996;157(4):1455-67.

26. Takasawa S, Tohgo A, Noguchi N, Koguma T, Nata K, Sugimoto T, et al. Synthesis and hydrolysis of cyclic ADP-ribose by human leukocyte antigen CD38 and inhibition of the hydrolysis by ATP. J Biol Chem. 1993;268(35):26052-4

27. Muñoz P, Navarro MD, Pavón EJ, Salmerón J, Malavasi F, Sancho J, et al. CD38 signaling in T cells is initiated within a subset of membrane rafts containing Lck and the CD3-zeta subunit of the T cell antigen receptor. J Biol Chem. 2003;278(50):50791-802.

28. Deaglio S, Dianzani U, Horenstein AL, Fernández JE, van Kooten C, Bragardo M, et al. Human CD38 ligand. A 120-KDA protein predominantly expressed on endothelial cells. J Immunol. 1996;156(2):727-34.

29. Deaglio S, Morra M, Mallone R, Ausiello CM, Prager E, Garbarino G, et al. Human CD38 (ADP-ribosyl cyclase) is a counter-receptor of CD31, an lg superfamily member. J Immunol. 1998;160(1):395-402.

30. Zupo S, Rugari E, Dono M, Taborelli G, Malavasi F, Ferrarini M. CD38 signaling by agonistic monoclonal antibody prevents apoptosis of human germinal center B cells. Eur J Immunol. 1994;24(5):1218-22.

31. Campana D, Suzuki T, Todisco E, Kitanaka A. CD38 in hematopoiesis. Chem Immunol. 2000;75:169-88.

32. Todisco E, Suzuki T, Srivannaboon K, Coustan-Smith E, Raimondi SC, Behm FG, et al. CD38 ligation inhibits normal and leukemic myelopoiesis. Blood. 2000;95(2):535-42.

33. Lund FE, Cockayne DA, Randall TD, Solvason N, Schuber F, Howard MC. CD38: a new paradigm in lymphocyte activation and signal transduction. Immunol Rev. 1998;161:79-93.

34. Cho YS, Han MK, Choi YB, Yun Y, Shin J, Kim UH. Direct interaction of the CD38 cytoplasmic tail and the Lck SH2 domain. J Biol Chem. 2000;275(3):1685-90

35. Tohgo A, Takasawa S, Noguchi N, Koguma T, Nata K, Sugimoto T, et al. Essential cysteine residues for cyclic ADP-ribose synthesis and hydrolysis by CD38. J Biol Chem. 1994;269(46):28555-7.

36. Dianzani U, Funaro A, DiFranco D, Garbarino G, Bragardo M, Redoglia $\mathrm{V}$, et al. Interaction between endothelium and CD4+CD45RA+ lymphocytes. J Immunol. 1994;153(3):952-9.

37. Deeks SG, Kitchen CMR, Liu L, Guo H, Gascon R, Narváez AB, et al. Immune activation set point during early HIV infection predicts subsequent CD4 ${ }^{+}$T-cell changes independent of viral load. Blood. 2004;104(4):942-7.

38. Karim R, Mack WJ, Stiller T, Operskalski E, Frederick T, Landay A, et al. Association of HIV clinical disease progression with profiles of early immune activation: Results from a cluster analysis approach. AIDS. 2013;27(9):1473-81.

39. Holm GH, Gabuzda D. Distinct mechanisms of CD4+ and CD8+ T-cell activation and bystander apoptosis induced by human immunodeficiency virus type 1 virions. J Virol. 2005:79(10):6299-311.

40. Appay V, Almeida JR, Sauce D, Autran B, Papagno L. Accelerated immune senescence and HIV-1 infection. Exp Gerontol. 2007;42(5):432-7

41. Méndez-Lagares G, Pozo-Balado MM, Genebat González M, García Pergañeda A, et al. Severe immune dysregulation affects CD4+CD25(hi)FoxP3+ regulatory T cells in HIV-infected patients with low-level CD4 T-cell repopulation despite suppressive highly active antiretroviral therapy. J Infect Dis. 2012;205(10):1501-9.

42. Weiss L, Piketty C, Assoumou L, Didier C, Caccavelli L, DonkovaPetrini $V$, et al. Relationship between regulatory $T$ cells and immune 
activation in human immunodeficiency virus-infected patients interrupting antiretroviral therapy. PLoS ONE. 2010;5(7):e11659.

43. Grossman Z, Meier-Schellersheim M, Sousa AE, Victorino RM, Paul WE. CD4+ T-cell depletion in HIV infection: are we closer to understanding the cause? Nat Med. 2002;8(4):319-23.

44. Hazenberg MD, Hamann D, Schuitemaker H, Miedema F. T cell depletion in HIV-1 infection: how CD4+ T cells go out of stock. Nat Immunol. 2000;1 (4):285-9.

45. Giorgi JV, Liu Z, Hultin LE, Cumberland WG, Hennessey K, Detels R. Elevated levels of CD38+CD8+ T cells in HIV infection add to the prognostic value of low CD4+ T cell levels: results of 6 years of follow-up. J Acquir Immune Defic Syndr. 1993;6(8):904-12.

46. Sousa AE, Carneiro J, Meier-Schellersheim M, Grossman Z, Victorino RM. CD4 T cell depletion is linked directly to immune activation in the pathogenesis of HIV-1 and HIV-2 but only indirectly to the viral load. J Immunol. 2002;169(6):3400-6.

47. Hunt PW, Martin JN, Sinclair E, Bredt B, Hagos E, Lampiris $H$, et al. $T$ cell activation is associated with lower CD4+ T cell gains in human immunodeficiency virus-infected patients with sustained viral suppression during antiretroviral therapy. J Infect Dis. 2003;187(10):1534-43.

48. Hunt PW, Brenchley J, Sinclair E, McCune JM, Roland M, Page-Shafer $\mathrm{K}$, et al. Relationship between T cell activation and CD4+ T cell count in HIV-seropositive individuals with undetectable plasma HIV RNA levels in the absence of therapy. J Infect Dis. 2008;197(1):126-33.

49. Rodríguez B, Sethi AK, Cheruvu VK, Mackay W, Bosch RJ, Kitahata M, et al. Predictive value of plasma HIV RNA level on rate of CD4 T-cell decline in untreated HIV infection. JAMA. 2006;296(12):1498-506.

50. Hazenberg MD, Otto SA, van Benthem BHB, Roos MTL, Coutinho RA, Lange JMA, et al. Persistent immune activation in HIV-1 infection is associated with progression to AIDS. AIDS. 2003;17(13):1881-8.

51. Jiang W, Lederman MM, Hunt P, Sieg SF, Haley K, Rodriguez B, et al. Plasma levels of bacterial DNA correlate with immune activation and the magnitude of immune restoration in persons with antiretroviraltreated HIV infection. J Infect Dis. 2009;199(8):1177-85.

52. Froebel KS, Raab GM, D'Alessandro C, Armitage MP, MacKenzie KM, Struthers $\mathrm{M}$, et al. A single measurement of CD38CD8 cells in $\mathrm{HIV}^{+}$, long-term surviving injecting drug users distinguishes those who will progress to AIDS from those who will remain stable. Clin Exp Immunol. 2000;122(1):72-8

53. Liu Z, Cumberland WG, Hultin LE, Kaplan AH, Detels R, Giorgi JV. CD8 ${ }^{+}$ T-lymphocyte activation in HIV-1 disease reflects an aspect of pathogenesis distinct from viral burden and immunodeficiency. J Acquir Immune Defic Syndr Hum Retrovirol. 1998;18(4):332-40.

54. Ondoa P, Koblavi-Dème S, Borget MY, Nolan ML, Nkengasong JN, Kestens $\mathrm{L}$. Assessment of $\mathrm{CD} 8^{+} \mathrm{T}$ cell immune activation markers to monitor response to antiretroviral therapy among HIV-1 infected patients in Cote d'Ivoire. Clin Exp Immunol. 2005;140(1):138-48.

55. Bandera A, Gori A, Clerici M, Sironi M. Phylogenies in ART: HIV reservoirs, HIV latency and drug resistance. Curr Opin Pharmacol. 201 9;48:24-32.

56. Zicari S, Sessa L, Cotugno N, Ruggiero A, Morrocchi E, Concato C, et al. Immune activation, inflammation, and non-AIDS CO-morbidities in HIVinfected patients under long-term ART. Viruses. 2019;11(3):200.

57. Collaboration TATC. Life expectancy of individuals on combination antiretroviral therapy in high-income countries: a collaborative analysis of 14 cohort studies. Lancet. 2008;372(9635):293-9.

58. Patterson S, Cescon A, Samji H, Chan K, Zhang W, Raboud J, et al. Life expectancy of HIV-positive individuals on combination antiretroviral therapy in Canada. BMC Infect Dis. 2015;15:274.

59. Wong JK, Hezareh M, Günthard HF, Havlir DV, Ignacio CC, Spina CA, et al. Recovery of replication-competent HIV despite prolonged suppression of plasma viremia. Science. 1997;278(5341):1291-5.

60. Sandler NG, Sereti I. Can early therapy reduce inflammation? Curr Opin HIV AIDS. 2014;9(1):72-9.

61. Amirayan-Chevillard N, Tissot-Dupont H, Capo C, Brunet C, DignatGeorge F, Obadia Y, et al. Impact of highly active anti-retroviral therapy (HAART) on cytokine production and monocyte subsets in HIV-infected patients. Clin Exp Immunol. 2000;120(1):107-12.

62. Funderburg NT, Andrade A, Chan ES, Rosenkranz SL, Lu D, Clagett B, et al. Dynamics of immune reconstitution and activation markers in
HIV+ treatment-naïve patients treated with raltegravir, tenofovir disoproxil fumarate and emtricitabine. PLoS One. 2013; 8(12):e83514.

63. Lederman MM. Immune restoration and CD4+ T-cell function with antiretroviral therapies. AIDS. 2001;15(Suppl 2):S11-5.

64. Cao WW, Jamieson BD, Hultin LE, Hultin PM, Detels R. Regulatory T cell expansion and immune activation during untreated HIV type 1 infection are associated with disease progression. AIDS Res Hum Retrov. 2009;25(2):183-91.

65. Asmuth DM, Ma ZM, Mann S, Knight TH, Yotter T, Albanese A, et al. Gastrointestinal-associated lymphoid tissue immune reconstitution in a randomized clinical trial of raltegravir versus non-nucleoside reverse transcriptase inhibitor-based regimens. AIDS. 2012;26(13):1625-34.

66. Hattab S, Guihot A, Guiguet M, Fourati S, Carcelain G, Caby F, et al. Comparative impact of antiretroviral drugs on markers of inflammation and immune activation during the first two years of effective therapy for HIV-1 infection: an observational study. BMC Infect Dis. 2014;14:122.

67. Koblavi-Dème S, Maran M, Kabran N, Borget MY, Kalou M, Kestens L, et al. Changes in levels of immune activation and reconstitution markers among HIV-1-infected Africans receiving antiretroviral therapy. AIDS. 2003;17(Suppl 3):S17-22.

68. Benito JM, López M, Lozano S, Ballesteros C, Martinez P, González-Lahoz $J$, et al. Differential upregulation of CD38 on different T-cell subsets may influence the ability to reconstitute $C D 4^{+} \mathrm{T}$ cells under successful highly active antiretroviral therapy. J Acquir Immune Defic Syndr. 2005:38(4):373-81.

69. de Carvalho PG, de Oliveira RR, da Silva SFR, Ribeiro IF, de Miranda Lucena HB, Martins LRC, et al. CD38+CD8+ and CD38+CD4+ T cells and IFN gamma (+874) polymorphism are associated with a poor virological outcome. Immunol Invest. 2016;45(4):312-27.

70. Lu W, Mehraj V, Vyboh K, Cao W, Li T, Routy JP. CD4:CD8 ratio as a frontier marker for clinical outcome, immune dysfunction and viral reservoir size in virologically suppressed HIV-positive patients. J Int AIDS Soc. 2015;18:20052.

71. Hunt PW, Hatano H, Sinclair E, Lee TH, Busch MP, Martin JN, et al. HIVspecific $C D 4^{+} T$ cells may contribute to viral persistence in HIV controllers. Clin Infect Dis. 2011;52(5):681-7.

72. Lok JJ, Hunt PW, Collier AC, Benson CA, Witt MD, Luque AE, et al. The impact of age on the prognostic capacity of $\mathrm{CD} 8^{+} \mathrm{T}$-cell activation during suppressive antiretroviral therapy. AIDS. 2013;27(13):2101-10.

73. Taiwo B, Hunt PW, Gandhi RT, Ellingson A, McKenna M, Jacobson JM, et al. CD8+ T-cell activation in HIV-1-infected patients experiencing transient low-level viremia during antiretroviral therapy. J Acquir Immune Defic Syndr. 2013;63(1):101-4.

74. Gras L, Jurriaans S, Bakker M, van Sighem A, Bezemer D, Fraser C, et al. Viral load levels measured at set-point have risen over the last decade of the HIV epidemic in the Netherlands. PLoS ONE. 2009;4(10):e7365.

75. Zhang ZN, Hu SW, Liu J, Xu JJ, He L, Jiang Y, et al. CD4+CD38+HLADR+ Cells: a predictor of viral set point in Chinese men with primary HIV infection who have sex with men. Jpn J Infect Dis. 2011;64(5):423-5.

76. Appay V, Kelleher AD. Immune activation and immune aging in HIV infection. Curr Opin HIV AIDS. 2016;11(2):242-9.

77. Schuetz A, Deleage C, Sereti I, Rerknimitr R, Phanuphak N, PhuangNgern $Y$, et al. Initiation of ART during early acute HIV infection preserves mucosal Th17 function and reverses HIV-related immune activation. PLoS Pathog. 2014;10(12):e1004543.

78. Goicoechea M, Smith DM, Liu L, May S, Tenorio AR, Ignacio CC, et al. Determinants of $\mathrm{CD}^{+} \mathrm{T}$ cell recovery during suppressive antiretroviral therapy: association of immune activation, T cell maturation markers, and cellular HIV-1 DNA. J Infect Dis. 2006;194(1):29-37.

79. Almeida M, Cordero M, Almeida J, Orfao A. Relationship between CD38 expression on peripheral blood T-cells and monocytes, and response to antiretroviral therapy: a one-year longitudinal study of a cohort of chronically infected ART-naive HIV-1 + patients. Cytometry B Clin Cytom. 2007;72(1):22-33.

80. Cannizzo ES, Bellistrì GM, Casabianca A, Tincati C, lannotti N, Barco A, et al. Immunophenotype and function of CD38-expressing $\mathrm{CD}^{+}{ }^{+}$and CD8 ${ }^{+} \mathrm{T}$ cells in HIV-infected patients undergoing suppressive combination antiretroviral therapy. J Infect Dis. 2015;211(9):1511-3.

81. Deeks SG, Walker BD. Human immunodeficiency virus controllers: mechanisms of durable virus control in the absence of antiretroviral therapy. Immunity. 2007;27(3):406-16. 
82. Sáez-Cirión A, Pancino G. HIV controllers: a genetically determined or inducible phenotype? Immunol Rev. 2013;254(1):281-94.

83. Sáez-Cirión A, Lacabaratz C, Lambotte O, Versmisse P, Urrutia A, Boufassa F, et al. HIV controllers exhibit potent CD8 T cell capacity to suppress HIV infection ex vivo and peculiar cytotoxic T lymphocyte activation phenotype. Proc Natl Acad Sci U S A. 2007;104(16):6776-81.

84. Chen HB, Piechocka-Trocha A, Miura T, Brockman MA, Julg BD, Baker $\mathrm{BM}$, et al. Differential neutralization of human immunodeficiency virus (HIV) replication in autologous CD4 T cells by HIV-specific cytotoxic T lymphocytes. J Virol. 2009;83(7):3138-49.

85. Doisne JM, Urrutia A, Lacabaratz-Porret C, Goujard C, Meyer L, Chaix $M L$, et al. CD8 ${ }^{+} T$ cells specific for EBV, cytomegalovirus, and influenza virus are activated during primary HIV infection. J Immunol. 2004;173(4):2410-8

86. Sáez-Cirión A, Sinet M, Shin SY, Urrutia A, Versmisse P, Lacabaratz C, et al. Heterogeneity in HIV suppression by CD8 T cells from HIV controllers: association with Gag-specific CD8 T cell responses. J Immunol. 2009;182(12):7828-37.

87. Gonzalez SM, Taborda NA, Correa LA, Castro GA, Hernandez JC, Montoya $\mathrm{CJ}$, et al. Particular activation phenotype of T cells expressing HLA-DR but not CD38 in GALT from HIV-controllers is associated with immune regulation and delayed progression to AIDS. Immunol Res. 2016;64(3):765-74.

88. Horton RE, McLaren PJ, Fowke K, Kimani J, Ball TB. Cohorts for the study of HIV-1-exposed but uninfected individuals: benefits and limitations. J Infect Dis. 2010;202(Suppl 3):S377-81.

89. Pancino G, Saez-Cirion A, Scott-Algara D, Paul P. Natural resistance to HIV infection: lessons learned from HIV-exposed uninfected individuals. J Infect Dis. 2010;202(Suppl 3):S345-50.

90. Shearer G, Clerici M. Historical perspective on HIV-exposed seronegative individuals: has nature done the experiment for us? I Infect Dis. 2010;202(Suppl 3):S329-32.

91. Oliveira LMS, Lima JF, Cervantes CAC, Casseb JS, Mendonça M, Duarte AJS, et al. Increased frequency of circulating Tc22/Th22 cells and polyfunctional CD38- T cells in HIV-exposed uninfected subjects. Sci Rep. 2015;5:13883

92. Migueles SA, Laborico AC, Shupert WL, Sabbaghian MS, Rabin R, Hallahan CW, et al. HIV-specific CD8+ T cell proliferation is coupled to perforin expression and is maintained in nonprogressors. Nat Immunol. 2002;3(11):1061-8.

93. Migueles SA, Osborne CM, Royce C, Compton AA, Joshi RP, Weeks $\mathrm{KA}$, et al. Lytic granule loading of CD8+ T cells is required for HIVinfected cell elimination associated with immune control. Immunity 2008;29(6):1009-21.

94. Hersperger AR, Pereyra F, Nason M, Demers K, Sheth P, Shin LY, et al. Perforin expression directly ex vivo by HIV-specific CD8 T-cells is a correlate of HIV elite control. PLoS Pathog. 2010;6(5):e1000917.

95. Addo MM, Draenert R, Rathod A, Verrill CL, Davis BT, Gandhi RT, et al. Fully differentiated HIV-1 specific CD8+T effector cells are more frequently detectable in controlled than in progressive HIV-1 infection. PLOS ONE. 2007;2(3):e321.

96. Julg B, Pereyra F, Buzón MJ, Piechocka-Trocha A, Clark MJ, Baker BM, et al. Infrequent recovery of HIV from but robust exogenous infection of activated CD4(+) T cells in HIV elite controllers. Clin Infect Dis. 2010;51(2):233-8.

97. Kiepiela P, Ngumbela K, Thobakgale C, Ramduth D, Honeyborne I, Moodley $E$, et al. CD8+ T-cell responses to different HIV proteins have discordant associations with viral load. Nat Med. 2007:13(1):46-53.

98. Pontesilli O, Klein MR, Kerkhof-Garde SR, Pakker NG, de Wolf F, Schuitemaker $\mathrm{H}$, et al. Longitudinal analysis of human immunodeficiency virus type 1-specific cytotoxic T lymphocyte responses: a predominant gag-specific response is associated with nonprogressive infection. J Infect Dis. 1998;178(4):1008-18.

99. Edwards BH, Bansal A, Sabbaj S, Bakari J, Mulligan MJ, Goepfert PA Magnitude of functional CD8+T-cell responses to the gag protein of human immunodeficiency virus type 1 correlates inversely with viral load in plasma. J Virol. 2002;76(5):2298-305.

100. Berger CT, Frahm N, Price DA, Mothe B, Ghebremichael M, Hartman KL, et al. High-functional-avidity cytotoxic T lymphocyte responses to HLAB-restricted Gag-derived epitopes associated with relative HIV control. J Virol. 2011;85(18):9334-45.
101. Mothe B, Llano A, Ibarrondo J, Zamarreño J, Schiaulini M, Miranda C, et al. CTL responses of high functional avidity and broad variant crossreactivity are associated with HIV control. PLoS ONE. 2012;7(1):e29717.

102. Descours B, Avettand-Fenoel V, Blanc C, Samri A, Mélard A, Supervie $V$, et al. Immune responses driven by protective human leukocyte antigen alleles from long-term nonprogressors are associated with low HIV reservoir in central memory CD4T cells. Clin Infect Dis. 2012;54(10):1495-503.

103. Hua S, Lécuroux C, Sáez-Cirión A, Pancino G, Girault I, Versmisse P, et al. Potential role for HIV-specific CD38-/HLA-DR ${ }^{+} \mathrm{CD}^{+} \mathrm{T}$ cells in viral suppression and cytotoxicity in HIV controllers. PLoS ONE. 2014;9(7):e101920.

104. Song CB, Zhang LL, Wu X, Fu YJ, Jiang YJ, Shang $H$, et al. $\mathrm{CD}^{+}{ }^{+} \mathrm{CD} 38^{+}$central memory T cells contribute to HIV persistence in HIV-infected individuals on long-term ART. J Transl Med. 2020;18(1):95.

105. Freguja R, Gianesin K, Mosconi I, Zanchetta M, Carmona F, Rampon $\mathrm{O}$, et al. Regulatory $\mathrm{T}$ cells and chronic immune activation in human immunodeficiency virus 1 (HIV-1)-infected children. Clin Exp Immunol. 2011;164(3):373-80.

106. Romeiro JR, Pinto JA, Silva ML, Eloi-Santos SM. Further evidence that the expression of CD38 and HLA-DR ${ }^{+}$in $\mathrm{CD}^{+}$lymphocytes does not correlate to disease progression in HIV-1 vertically infected children. J Int Assoc Phys AIDS Care (Chic). 2012;11(3):164-8.

107. Chavan S, Bennuri B, Kharbanda M, Chandrasekaran A, Bakshi S, Pahwa $\mathrm{S}$. Evaluation of $\mathrm{T}$ cell receptor gene rearrangement excision circles after antiretroviral therapy in children infected with human immunodeficiency virus. J Infect Dis. 2001;183(10):1445-54.

108. Ometto L, De Forni D, Patiri F, Trouplin V, Mammano F, Giacomet V, et al. Immune reconstitution in HIV-1-infected children on antiretroviral therapy: role of thymic output and viral fitness. AIDS. 2002;16(6):839-49.

109. De Rossi A, Walker AS, Klein N, De Forni D, King D, Gibb DM. Increased thymic output after initiation of antiretroviral therapy in human immunodeficiency virus type 1-infected children in the Paediatric European Network for Treatment of AIDS (PENTA) 5 Trial. J Infect Dis. 2002;186(3):312-20.

110. Anselmi A, Vendrame D, Rampon O, Giaquinto C, Zanchetta M, De Rossi A. Immune reconstitution in human immunodeficiency virus type 1-infected children with different virological responses to anti-retroviral therapy. Clin Exp Immunol. 2007;150(3):442-50.

111. Musyoki S, Mining S, Nyongesa P. Level of CD8 T lymphocytes activation in HIV-infected pregnant women: in the context of CD38 and HLA-DR activation markers. Interdiscip Perspect Infect Dis. 2014;2014(2014):715279.

112. Sachdeva N, Oshima K, Cotter A, Ashman M, Davila L, Okazaki T, et al. Analysis of immunological markers associated with pregnancy and HIV-1 infection: relevance in perinatal transmission in HIV-1-infected pregnant women with low plasma viral load. Am J Reprod Immunol. 2008;60(3):264-73.

113. Mikyas Y, Aziz N, Harawa N, Gorre M, Neagos N, Nogueira M, et al. Immunologic activation during pregnancy: serial measurement of lymphocyte phenotype and serum activation molecules in HIV-infected and uninfected women. J Reprod Immunol. 1997;33(2):157-70.

114. Burns DN, Nourjah P, Wright DJ, Minkoff H, Landesman S, Rubinstein $A$, et al. Changes in immune activation markers during pregnancy and postpartum. J Reprod Immunol. 1999:42(2):147-65.

115. Truong HM, Sim MS, Dillon M, Uittenbogaart CH, Dickover R, Plaeger SF, et al. Correlation of immune activation during late pregnancy and early postpartum with increases in plasma HIV RNA, CD4/CD8 T cells, and serum activation markers. Clin Vaccine Immunol. 2010;17(12):2024-8.

116. Silver RM. Immune activation early in pregnancy: trouble down the road? Am J Obstet Gynecol. 2008;199(4):327-8.

117. Mor G, Aldo P, Alvero AB. The unique immunological and microbial aspects of pregnancy. Nat Rev Immunol. 2017;17(8):469-82.

118. Masters MC, Ances BM. Role of neuroimaging in HIV-associated neurocognitive disorders. Semin Neurol. 2014;34(1):89-102.

119. Mamik MK, Banerjee S, Walseth TF, Hirte R, Tang L, Borgmann K, et al. HIV-1 and IL-1 $\beta$ regulate astrocytic CD38 through mitogen-activated protein kinases and nuclear factor-KB signaling mechanisms. J Neuroinflammation. 2011;8:145.

120. Dentone C, Fenoglio D, Schenone E, Cenderello G, Prinapori R, Signori $A$, et al. Increased CD38 expression on T lymphocytes as a marker 
of HIV dissemination into the central nervous system. HIV Clin Trials. 2015;16(5):190-6.

121. Lins L, Farias E, Brites-Alves C, Torres A, Netto EM, Brites C. Increased expression of CD38 and HLADR in HIV-infected patients with oral lesion. J Med Virol. 2017:89(10):1782-7.

122. Gonzalez VD, Falconer K, Blom KG, Reichard O, Mørn B, Laursen AL, et al. High levels of chronic immune activation in the T-cell compartments of patients coinfected with hepatitis $C$ virus and human immunodeficiency virus type 1 and on highly active antiretroviral therapy are reverted by alpha interferon and ribavirin treatment. J Virol. 2009;83(21):11407-11.

123. d'Ettorre G, Ceccarelli G, Serafino S, Giustini N, Cavallari EN, Bianchi L, et al. Dominant enrichment of phenotypically activated CD38(+) HLA$\mathrm{DR}(+) \mathrm{CD} 8(+) \mathrm{T}$ cells, rather than CD38(+) HLA-DR(+) CD4(+) T cells, in HIV/HCV coinfected patients on antiretroviral therapy. J Med Virol. 2016;88(8):1347-56.

124. Cao W, Qiu ZF, Li TS. Parallel decline of CD8+CD38+ lymphocytes and viremia in treated hepatitis B patients. World J Gastroenterol. 2011;17(17):2191-8.

125. Zhu Y, Zhang ZG, Jiang Z, Liu Y, Zhou JW. CD38 predicts favorable prognosis by enhancing immune infiltration and antitumor immunity in the epithelial ovarian cancer microenvironment. Front Genet. 2020;11:369.

126. Malavasi F, Deaglio S, Damle R, Cutrona G, Ferrarini M, Chiorazzi N. CD38 and chronic lymphocytic leukemia: a decade later. Blood. 2011;118(13):3470-8.

127. Bras AE, Beishuizen A, Langerak AW, Jongen-Lavrencic M, Te Marvelde $J G$, van den Heuvel-Eibrink MM, et al. CD38 expression in paediatric leukaemia and lymphoma: Implications for antibody targeted therapy. Br J Haematol. 2016;180(2):292-6.

128. van de Donk NWCJ, Janmaat ML, Mutis T, Lammerts van Bueren JJ, Ahmadi T, Sasser AK, et al. Monoclonal antibodies targeting CD38 in hematological malignancies and beyond. Immunol Rev. 2016; 270(1): 95-112.

129. Poret N, Fu QW, Guihard S, Cheok M, Miller K, Zeng G, et al. CD38 in hairy cell leukemia is a marker of poor prognosis and a new target for therapy. Cancer Res. 2015;75(18):3902-11.

130. Thompson PA, Tam CS. CD38 expression in CLL: a dynamic marker of prognosis. Leuk Lymphoma. 2014:55(1):1-2.

131. Liao C, Shen DY, Xu XJ, Song H, Xu WQ, Zhao FY, et al. High CD38 expression in childhood T-cell acute lymphoblastic leukemia is not associated with prognosis. Cancer Biomark. 2020;27(2):277-84.

132. Overdijk MB, Verploegen $S$, Bögels $M$, van Egmond $M$, van Bueren JJL, Mutis T, et al. Antibody-mediated phagocytosis contributes to the antitumor activity of the therapeutic antibody daratumumab in lymphoma and multiple myeloma. MAbs. 2015;7(2):311-21.

133. Nijhof IS, van de Donk NWCJ, Zweegman S, Lokhorst HM. Current and new therapeutic strategies for relapsed and refractory multiple myeloma: an update. Drugs. 2018;78(1):19-37.

134. Partidá-Sánchez S, Rivero-Nava L, Shi G, Lund FE. CD38: an ecto-enzyme at the crossroads of innate and adaptive immune responses. Adv Exp Med Biol. 2006;590:171-83.

135. Chang XT, Yue LT, Liu WB, Wang Y, Wang L, Xu B, et al. CD38 and E2F transcription factor 2 have uniquely increased expression in rheumatoid arthritis synovial tissues. Clin Exp Immunol. 2014;176(2):222-31.

136. Cole S, Walsh A, Yin XF, Wechalekar MD, Smith MD, Proudman SM, et al. Integrative analysis reveals CD38 as a therapeutic target for plasma cell-rich pre-disease and established rheumatoid arthritis and systemic lupus erythematosus. Arthritis Res Ther. 2018;20(1):85.

137. Würsch D, Ormsby CE, Romero-Rodríguez DP, Olvera-García G, Zúñiga J, Jiang W, et al. CD38 expression in a subset of memory T cells is independent of cell cycling as a correlate of HIV disease progression. Dis Markers. 2016;2016:9510756

138. Quarona V, Zaccarello G, Chillemi A, Brunetti E, Singh VK, Ferrero E, et al. CD38 and CD157: A long journey from activation markers to multifunctional molecules. Cytometry B Clin Cytom. 2013:84(4):207-17.

139. Kim BJ, Choi YM, Rah SY, Park DR, Park SA, Chung YJ, et al. Seminal CD38 is a pivotal regulator for fetomaternal tolerance. Proc Natl Acad Sci U S A. 2015;112(5):1559-64.

140. Steel A, John L, Shamji MH, Henderson DC, Gotch FM, Gazzard BG, et al. CD38 expression on CD8 T cells has a weak association with CD4 T-cell recovery and is a poor marker of viral replication in HIV-1-infected patients on antiretroviral therapy. HIV Med. 2008;9(2):118-25.

141. Davis LC, Morgan AJ, Chen JL, Snead CM, Bloor-Young D, Shenderov E, et al. NAADP activates two-pore channels on T cell cytolytic granules to stimulate exocytosis and killing. Curr Biol. 2012;22(24):2331-7.

142. Melzer N, Hicking G, Göbel K, Wiendl H. TRPM2 cation channels modulate $T$ cell effector functions and contribute to autoimmune CNS inflammation. PLoS ONE. 2012;7(10):e47617.

143. Ernst IMA, Fliegert R, Guse AH. Adenine dinucleotide second messengers and T-lymphocyte calcium signaling. Front Immunol (electronic resource). 2013:4:259.

144. Wolf IMA, Diercks BP, Gattkowski E, Czarniak F, Kempski J, Werner R, et al. Frontrunners of $\mathrm{T}$ cell activation: initial, localized $\mathrm{Ca}^{2+}$ signals mediated by NAADP and the type 1 ryanodine receptor. Sci Signal. 2015;8(398):ra102

145. Rodríguez-Alba JC, Abrego-Peredo A, Gallardo-Hernández C, Pérez-Lara J, Santiago-Cruz W, Jiang W, et al. HIV disease progression: overexpression of the ectoenzyme CD38 as a contributory factor? BioEssays. 2019;41(1):e1800128.

146. Koppenol WH, Bounds PL, Dang CV. Otto Warburg's contributions to current concepts of cancer metabolism. Nat Rev Cancer. 2011;11(5):325-37.

147. Rajasuriar R, Khoury G, Kamarulzaman A, French MA, Cameron PU, Lewin SR. Persistent immune activation in chronic HIV infection: do any interventions work? AIDS. 2013;27(8):1199-208.

148. Moodley K, Coetzee LM, Glencross DK. Decentralised CD38 activation monitoring: Aspects of practical implementation and standardisation. J Immunol Methods. 2012:378(1-2):121-7.

149. Malavasi F, Funaro A, Roggero S, Horenstein A, Calosso L, Mehta K. Human CD38: a glycoprotein in search of a function. Immunol Today. 1994;15(3):95-7.

150. Hunt PW, Martin JN, Sinclair E, Epling L, Teague J, Jacobson MA, et al. Valganciclovir reduces T cell activation in HIV-infected individuals with incomplete CD4+ T cell recovery on antiretroviral therapy. J Infect Dis. 2011:203(10):1474-83.

\section{Publisher's Note}

Springer Nature remains neutral with regard to jurisdictional claims in published maps and institutional affiliations.

Ready to submit your research? Choose BMC and benefit from:

- fast, convenient online submission

- thorough peer review by experienced researchers in your field

- rapid publication on acceptance

- support for research data, including large and complex data types

- gold Open Access which fosters wider collaboration and increased citations

- maximum visibility for your research: over $100 \mathrm{M}$ website views per year

At $\mathrm{BMC}$, research is always in progress.

Learn more biomedcentral.com/submissions 